\title{
Proposed method for estimating the costs of safety barrier life cycle
}

\author{
Kazimierz Jamroz ${ }^{1, *}$, Anna Gobis ${ }^{1}$, Adam Kristowski ${ }^{2}$, and Beata Grzyl $^{2}$ \\ ${ }^{1}$ Gdansk University of Technology, Faculty Of Civil and Environmental Engineering, Highway and \\ Transportation Engineering Department, 11/12 Narutowicza Str., 80-233, Gdansk, Poland \\ ${ }^{2}$ Gdansk University of Technology, Faculty Of Civil and Environmental Engineering, Metal \\ Structures and Construction Management Department, 11/12 Narutowicza Str., 80-233, Gdansk, \\ Poland
}

\begin{abstract}
Today barrier types are frequently selected for their price with little regard for the total costs the structure will incur over its lifetime. One of the basic tools designed to manage road infrastructure is the life cycle cost method (LCC, Life cycle cost). It sums up the costs to plan, design, build, operate (use and maintain) and decommission a road structure. Having developed dynamically at the turn of the century the method is now widely applied in a number of industries including traffic engineering. Today, depending on data availability and calculation complexity, two groups of life cycle assessments are distinguished: analytical and parametric. Unfortunately, each comes with some limitations and the search for a new universal life cycle cost calculation method continues. The authors propose their own general concept of a method for estimating the life cycle costs of road safety barriers. The article presents a multi-stage process to build the method which is based on international experience and real test site data.
\end{abstract}

\section{Introduction}

Construction works including safety barriers, must be designed and built in such a way that they will stay durable and useable during their entire life cycle [1]. In practice decisions to buy a specific type of safety barrier are based on construction costs. When barriers are designed and selected, the costs to be borne by users and road infrastructure managers for maintenance and operation over extended periods (30 - 50 years) are often overlooked. Safety barrier crashes are frequent with more than $2 \%$ of collisions in Poland involving vehicles hitting a barrier as study results show. Based on this it is estimated that the costs to replace damaged parts of barriers during their working life (maintenance, repairs, replacement, modernisation, maintaining proper safety standards) exceed the construction costs significantly [2]. As a result, methods and solutions are investigated to improve cost effectiveness and reduce the costs of maintenance and use of existing roads and road safety devices. One tool that can help to manage and plan infrastructure optimally is the life cycle cost method, the LCC. Already a widely applied method in road infrastructure management, in the future it can prove to be the basic tool for investment decisions. As a consequence,

* Corresponding author: kjamroz@pg.edu.pl 
road authorities are encouraged to use the LCC analysis, e.g. when conducting public tenders because the life cycle cost of a structure is a recommended parameter for selecting road design alternatives and evaluating bids [3].

The research project LifeRoSE includes the task "Studying the effects of durability and functionality on safety and life cycle costs of road safety devices". Part of the task is to develop a method for assessing the life cycle costs of safety barriers and other road safety devices.

\section{Development of methods for assessing life cycle costs}

The life cycle cost assessment was first conducted in the United States in the late 1960s for military purposes. In 1983 US Navy published a handbook [4] on how the life cycle cost analysis method should be used in managing Navy resources. With the handbook giving it a good start, the LCC developed dynamically in other industries, primarily in aviation, power sector, chemical industry and rail [5]. With time the method proved useful for assessing the costs of road infrastructure life cycle for a variety of structures, durability and service life $[2,6,7]$.

The theoretical basis for integrated product life cycle management is comprised of selected theories, concepts and methods, and in particular: system theory and engineering [8], [9] concept of sustainable development [10], concept of life cycle thinking [11], risk management methods $[12,13]$, value-based management [14], reliability and functionality management [15].

Life cycle thinking (LCT) includes two groups of actions: life cycle management (LCM) and life cycle assessment comprising partial assessments:

- environmental life cycle assessment (E-LCA),

- social life cycle assessment (S-LCA),

- life cycle cost assessment (LCCA).

Different types of assets are assessed with different life cycle cost assessment methods, LCC. The life cycle costs of an asset are the estimated costs borne throughout an asset's life cycle from planning and design, through construction or purchase, operation over the years until decommissioning. The LCC life cycle cost assessment method is a general method which helps to: specify and compare the particular elements of asset costs and compare construction alternatives and product alternatives, etc. LCC life cycle cost assessment methods can be divided into two groups: analytical and parametric (practical) methods [2].

Analytical methods are used to assess the outcomes of decisions from the scientific perspective. This approach includes a set of analytical tools to help with decision-making. They are: check lists, computer simulations, set of mathematical models (e.g. accident models, delay models).

Developed by governments and company boards parametric methods include simplified qualitative procedures for assessing costs and are frequently presented as guidelines. These methods work well in strategic analyses where a high accuracy of cost estimation is not required. Both approaches come with certain limitations. They may be the following:

- on the one hand, if not all of the components of a road asset's life cycle costs are included, it is likely that the cheapest option will be selected and as such generate high operating and maintenance costs,

- on the other hand, if conducted poorly, LCC analysis may suggest that a more expensive option should be selected putting the investor's budget at risk; this is because contractors rise to the occasion and try to sell the most expensive solution on the promise of a long life cycle which cannot be verified because the method is not robust enough [16].

As a result, new scientific methods are investigated with the aim of producing practical solutions [17]. 
In highway engineering LCC is a basic element of a set of methods for road infrastructure management, i.e. Road Asset Management [18], [19]. The method is also applied to bridges (whose life cycle is up to 100 years) [6]. It is used for selecting road surfaces (a life cycle of 30 years) [7]. In recent years, LCC has been used in other fields of highway engineering, e.g. to help select types of safety barriers. Life cycle cost analysis has been used to assess safety barrier life cycle in the United Kingdom, Sweden and the US [2], [20], [21].

In the United Kingdom, commissioned by the Highway Agency, the TRL developed a method for analysing the life cycle costs of safety barriers to help with barrier selection [20]. The Whole Life Cost (WLC) method was used under the following assumptions:

- the service life of concrete barriers was calculated at 50 years and 25 for metal barriers assuming that they will be replaced after that period; the service life of safety barriers is influenced by the following factors: type of safety barrier, quality of materials, manufacture and installation of barriers, in-use conditions (traffic volume and composition, vehicle speeds), the external environment and maintenance conditions.

- four stages are distinguished in barrier service life: initial installation (construction), maintenance, repairs (after a vehicle has crashed into a barrier), removal (barrier end of life); because each stage is vital and may substantially influence the costs, the analysis should report them to be able to watch the particular barrier service life phases and respond as appropriate.

- seven types of costs were analysed related to: safety, barrier installation, general maintenance, repairs, removal, traffic management and traffic delays; many of the cost components were excluded from whole life costing because they are either too sitespecific or too complicated (e.g. costs of damage to objects which the barriers protected, costs of complete road closure to remove a vehicle).

In Sweden the Swedish Road Agency (SRA) developed a detailed method for assessing the life cycle costs of road structures with a special focus on safety barriers. The methods used included the analytical approach with multi-stage models for identifying and estimating components of fixed and variable costs, the Monte Carlo method for analysing uncertainty and risk analysis and assessment for cost management. For practical purposes (mainly for strategic analyses) a parametric simplified method was developed. The method for cost assessment and analysis consisted of several steps: defining the objective of analysis, the approach and cost components; identifying components of safety barrier life cycle, identifying cost components (including investment costs, maintenance costs and user social costs), developing models for assessing the individual cost components and validating the method. The method was used to analyse life cycle costs and compare different types of safety barriers [2].

Elements of LCC were also used to assess cable median barriers and three most popular types of concrete median barriers in Texas. Cost data were collected and compared as regards the installation, repairs and maintenance (recurring costs) of barriers. When assessing recurring costs, the frequency of crashes and road surface condition in different regions were considered. Eventually, an LCC comparative analysis was made for a 5 mile section (app. 8 $\mathrm{km}$ ) under the following assumptions:

- barrier service life is 15 years,

- discount rate at $5 \%$,

- recurring costs of cable barriers: $\$ / 4250$ mile/year,

- recurring costs of concrete barriers: $\$ / 250 /$ mile/year.

With this number of simplifications and two categories of costs, the US method is relatively simple to use [21]. 


\section{Developing a method for life cycle cost assessment}

A multi-stage process was adopted for developing an LCC life cycle cost assessment method for safety barriers:

1. Identify the need for the method

2. Assumptions

3. Develop a general concept of a cost assessment method

4. Build a database with costs of barrier damage

5. Develop a set of models for assessing parameters and independent variables

6. Develop a calculation procedure

7. Verify the method

8. Develop principles of how the method should be used

Identify the need for the method. Safety barriers are a special engineering device whose elements (sections) may become damaged more than once during their working life. The scope of the damage depends on a number of factors which include: road class, type of barrier, its location, type and volume of traffic, vehicle speed, etc. The number of hazardous incidents (a vehicle hitting a median barrier) was studied on six selected test sections. It was found that within a year some $0.8-2.8 \%$ of barrier length may become damaged depending on road class and traffic volume (Table 1). Following from that it was estimated that within 30 years of a road's service life $25-85 \%$ of median barrier length may become damaged and may need replacing.

Based on the initial study (Table 1) it was estimated that annually on a $10 \mathrm{~km}$ stretch of a rural double carriageway a safety barrier may be hit $5-20$ times.

Tab. 1 Selected road sections from a test site and the average number and length of recorded damage in 2017.

\begin{tabular}{|c|c|c|c|c|c|c|c|}
\hline \multirow{2}{*}{$\begin{array}{l}\text { Road } \\
\text { section }\end{array}$} & $\begin{array}{l}\text { Length } \\
\text { of } \\
\text { section }\end{array}$ & $\begin{array}{l}\text { Traffic } \\
\text { volume }\end{array}$ & $\begin{array}{c}\text { Share of } \\
\text { HGVs }\end{array}$ & $\begin{array}{l}\text { Speed } \\
\text { limit }\end{array}$ & $\begin{array}{l}\text { Damage } \\
\text { quantity }\end{array}$ & $\begin{array}{l}\text { Length of } \\
\text { damage }\end{array}$ & $\begin{array}{c}\text { Share of } \\
\text { damaged } \\
\text { barriers }\end{array}$ \\
\hline & $\begin{array}{l}\mathrm{Ls} \\
{[\mathrm{km}]}\end{array}$ & $\begin{array}{c}\text { AADT } \\
\text { tho. veh/day] }\end{array}$ & $\begin{array}{l}\mathrm{PHV} \\
{[\%]}\end{array}$ & $\begin{array}{c}\mathrm{Vd} \\
{[\mathrm{km} / \mathrm{h}]}\end{array}$ & $\begin{array}{c}\mathrm{Nd} \\
\text { [pcs./year] }\end{array}$ & $\begin{array}{c}\mathrm{Ld} \\
{[\mathrm{km} / \text { year}]}\end{array}$ & $\begin{array}{c}\mathrm{Pd} \\
{[\%]}\end{array}$ \\
\hline A1 & 92.6 & 20.7 & 25.0 & 140 & 102 & 2.576 & 2.78 \\
\hline A1 & 48.7 & 18.9 & 22.4 & 140 & 24 & 0.368 & 0.76 \\
\hline S6 & 36.5 & 61.7 & 17.3 & 120 & 74 & 0.760 & 2.08 \\
\hline S8 & 84.0 & 28.9 & 38.9 & 120 & 72 & 1.456 & 1.73 \\
\hline DK01 & 18.9 & 43.4 & 23.3 & 100 & 28 & 0.520 & 2.74 \\
\hline DK01 & 28.5 & 37.9 & 33.0 & 100 & 42 & 0.376 & 1.32 \\
\hline
\end{tabular}

The consequences for road users are serious with financial losses and social consequences of accidents, delays caused by road blockage or as a result of lower speeds and reduced capacity when accident scenes are cleared and devices are repaired if damaged in a hazardous incident. With new road maintenance standards in place, there is a need to use analytical tools to help with making reasonable barrier choices and estimating the maintenance costs of existing barriers. Support is needed for road authorities, road designers and contractors by offering them a method for analysing the life cycle costs of safety barriers.

Assumptions. The following assumptions have been made for the LCC method:

1. The method is for safety barriers which are divided based on: where they are located on a road cross-section into: median and roadside barriers; the material used: steel, wire rope or concrete; designation: road or bridge.

2. Two approaches were used in developing the method: analytical and parametric. The analytical approach includes the authors' multi-stage mathematical models for identifying 
and assessing components of fixed and variable costs, the Monte Carlo method for uncertainty analysis and risk assessment for cost management. As regards the practical objectives (mainly initial and strategic analyses) a simplified parametric method was proposed for safety barrier life cycle cost assessment.

3. With some modification the method can be used for assessing the life cycle costs of other road safety devices (terminals, barrier cushions, vertical and horizontal marking).

Key to this is that the method should not generate more work or higher costs compared to the benefits of using it.

General concept of a life cycle cost assessment method. Once a cost assessment method is accepted at the planning and design stage, this will have a bearing on how the cost analysis (LCCA) will be conducted at the successive life cycle stages. It is important for a cost assessment method to define and adopt the goal and scope of analysis, time horizon, set of cost components, data collection, cost component estimation, set of basic economic efficiency measures and reporting.

The objective of the proposed cost assessment method is to estimate the costs of safety barrier construction and operation in the life cycle of a road structure. Considering Poland's average working life of a road, for calculation purposes the proposed time horizon is $\mathrm{T}=30$ years, i.e. the safety barrier's life cycle.

The process of cost component identification helped to distinguish several approaches to how the cost components of safety barrier life cycle can be classified. They fall into different groups depending on the cost owner, life cycle stages and type of costs:

a. costs borne by cost owners are divided into road authority and road user costs following this relation (1):

$$
L C C_{b}=C_{r a}+C_{r u}
$$

b. analysis of safety barrier life cycle stages has identified: investment costs, barrier maintenance costs, user costs when driving and barrier utilisation costs according to this relation (2):

$$
L C C_{b}=C_{i n}+C_{m a}+C_{r u}+C_{u t}
$$

c. during analysis of types of costs in the entire safety barrier life cycle, two groups have been identified: fixed and variable costs which are calculated using this relation (3):

$$
L C C_{b}=C F_{b}+\sum_{i=1}^{T} \frac{C V_{b_{i}}}{(1+a)^{T}}
$$

where:

$L C C_{b}$ - safety barrier life cycle costs, $C_{r a}$ - road authority costs, $C_{r u}$ - road users costs, $C_{i n}$ -investment costs, $C_{m a}$ - barrier maintenance costs, $C_{u t}$ - utilization costs, $C F_{b}$ - fixed costs, $C V_{b}$ - variable costs, $a$ - discount rate, $i$ - analysis year, $T$ - analysis period (years of barrier life cycle).

Further in the work the cost classification follows cost types which are: fixed costs and variable costs. As a result, the cost structure now includes the costs identified in the other classifications.

Fixed costs $C F_{b}$ only occur once; the proposed method considers three components of fixed costs described with this relation (4):

$$
C F_{b}=C_{p d}+C_{c o}+C_{m o}
$$

where:

$C_{p d}$ - preparatory work costs (study costs, planning and design costs), 
$C_{c o}$ - construction costs (costs to buy and build barriers on a road section),

$C_{m o}-$ modernisation costs, if any (costs to renew or replace barriers) during road structure service life.

Variable costs $C V_{b}$ recur throughout each year. The proposed method looks at four cost components described with this relation (5):

$$
C V_{b}=C_{m a}+C_{r u}+C_{u t}+C_{o t}
$$

where:

$C_{m a}$ - barrier maintenance costs (costs of day-to-day maintenance and costs to repair damaged barriers),

$C_{r u}$ - road user costs (road accident costs, user delay costs),

$C_{u t}$ - removal and utilization costs,

$C_{o t}$ - other costs.

Surveys, field studies, numerical analyses, computer simulations and expert opinions are now being conducted to identify the particular cost components.

Build a database with costs of barrier damage and repairs. Using data from road authorities responsible for the agreed test site (app. $3000 \mathrm{~km}$ of national roads), a database was built with costs of safety barrier damage and repairs.

The database is a source of information about the components of both fixed and variable costs. Fig. 1 shows examples of histograms and distribution patterns of total repair costs of steel barriers. The results show a significant spread of the repair costs ranging from PLN 280 to PLN 50500 with an average of PLN 4200. The analyses suggest that the distribution of barrier repair cost frequency is best described with Log-normal distribution. Similar distributions were calculated for the other types of safety barriers.

Further work. The data are used to carry out the next stages of the work which is to develop change models that are required to assess the costs of parameters depending on the significant set of independent variables. Models will be built such as mathematical models of barrier damage and deterioration, models of road accident and crash numbers and consequences involving safety barriers and delays on the part of road users as a result of barrier accidents and repairs. The models will provide a fairly accurate assessment of road user costs. The final stage will be designed to verify the method and develop instructions of use.
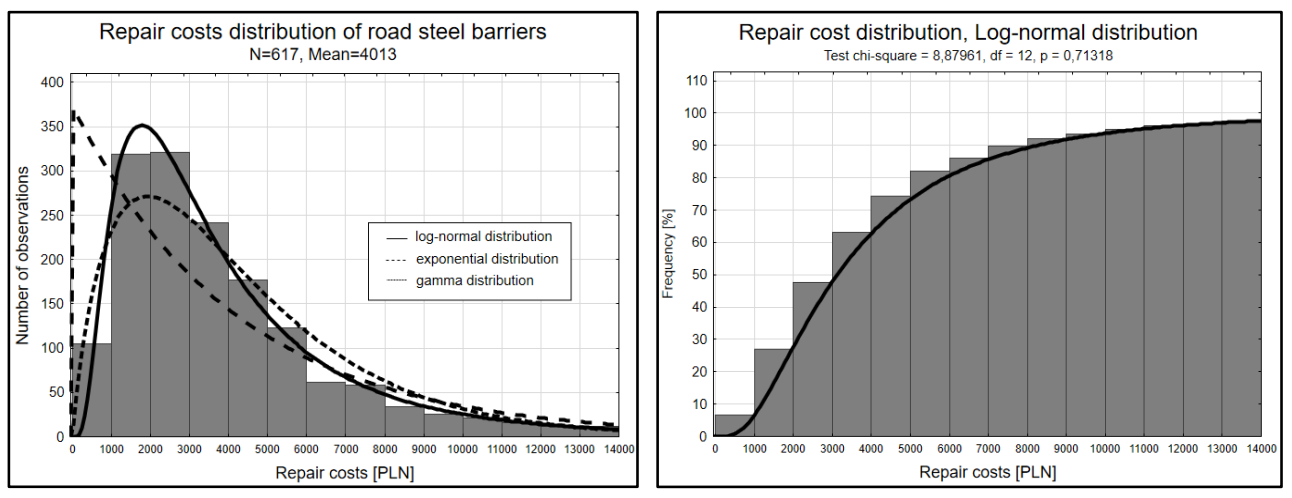

Fig. 1. Histogram and distribution of steel barrier repair costs (EURO $1 \approx$ PLN 4.27). Source: authors' work. 


\section{Summary}

The proposed method for safety barrier life cycle cost assessment will provide a tool for sustainable road infrastructure management. It will help to identify the cost components at each stage of barrier life cycle making it easier to identify those activities which may reduce the total costs of road infrastructure and maximise the socio-economic benefits. If used in practice, this universal method will help to reduce the scope and frequency of maintenance and repair work while ensuring that the safety standards of barriers are met, barriers are in use longer and road authorities' and maintenance services' outlays on road infrastructure can be reduced. The method is well suited not only for structure management, but also for better design decisions. The proposed method offers a novel approach to comprehensive assessment of safety barrier life cycle costs because it views life cycle costs from the investor's and road user's perspective.

The concept of a safety barrier life cycle cost assessment method was developed in a research project commissioned by the NCBiR (National Centre for Research and Development) and GDDKiA (General Directorate for National Roads and Motorways): Project RID 3B "The effects of time and in-use conditions on the durability and functionality of road safety devices".

\section{References}

1. Regulation (EU) No. 305/2011 of the European Parliament and of the Council of 9 March 2011 laying down harmonised conditions for the marketing of construction products and repealing Council Directive 89/106/EEC (2011)

2. H. Karim, R. Magnusson, K. Natanaelsson, Life-Cycle Cost Analyses for Road Barriers, J. Transp. $\quad$ Eng. 138 pp. 830-851 (2012). doi:https://doi.org/10.1061/(ASCE)TE.1943-5436.0000391

3. Directive 2014/24/EU of the European Parliament and of the Council of 26 February 2014 on public procurement and repealing Directive 2004/18/EC, (2014)

4. Military Handbook. Life Cycle Cost in Navy Acquisitions (Department of Defense United States of America, 1983)

5. A. Tułecki, M. Szkoda, Koszt cyklu trwałośći LCC jako model decyzyjny modernizacji pojazdów szynowych, Zesz. Nauk. Inst. Pojazdów. 64 pp. 10 (2007)

6. M. Szeremeta, T. Siwowski, Zastosowanie analizy typu LCCA do oceny wariantów modernizacji mostu, Arch. Inst. Inżynierii Lądowej / Politech. Poznańska. 18 pp. 203 214 (2014)

7. TP3/2010, Stavitel'stve, Technické Podmienky. Metodika stanovenia finančných kritérií na výber hornej stavby vozoviek v cestnom, (2010)

8. W.F. Blanchard, B., Systems Engineering and Analysis (Prentice Hall, Upper Saddle River, New Jersey, USA, 1998)

9. Y. Bijan, J. Yu, J. Stracener, T. Woods, Systems Requirements Engineering - State of the Metodology, Syst. Eng. $16 \quad$ pp. 267-276 (2012). doi:https://doi.org/10.1002/sys.21227

10. S. Neugebauer, S. Forin, M. Finkbeiner, From Life Cycle Costing to Economic Life Cycle Assessment - Introducing an Economic Impact Pathway, Sustainability. 8 pp. 428 (2016). doi:10.3390/su8050428

11. UNEP/SETAC, Greening the Economy Through Life Cycle Thinking. Ten Years of the UNEP/SETAC Life Cycle Initiative (United Nations Environment Programme, 2012) 
12. K. Jamroz, Country Safety Performance Function and the factors affecting it, in: Saf. Reliab. Methodol. Appl., pp. 101-108 (2015)

13. K. Jamroz, M. Budzyński, W. Kustra, L. Michalski, S. Gaca, Tools for road infrastructure safety management - Polish experiences, in: Transp. Res. Procedia, pp. 730-739 (2014). doi:10.1016/j.trpro.2014.10.052

14. National Academies of Sciences Engineering and Medicine, Value engineering applications in transportation: a synthesis of highway practice (The National Academies Press, 2005). doi:https://doi.org/10.17226/13869

15. Ł. Jeliński, K. Jamroz, J. Jamroz, M. Antoniuk, Functionality of road safety devices identification and analysis of factors, MATEC Web Conf. 122 (2017). doi:10.1051/matecconf/201712202005

16. M. Stenbeck, A. Hjern, Social consequences of illness (Chapter 5), Int. J. Soc. Welf. 16 pp. 105-126 (2007). doi:10.1111/j.1468-2397.2007.00518.x

17. UNEP/SETAC Life cycle Initiative, Life Cycle approaches: The road from analysis to practice (UNEP, 2005)

18. F. Pasquali, G. Poirier, J. Perol, S. Gerard, F. Pasquali, S. Baietti, J. Van Der Velde, J. Schavemaker, V. Vilanova, G.A. Hofman, B. Pengal, J. Duchoud, R. Arrowsmith, Life Cycle Costs and NRAs. Investigation of the application of LCC principles by selected NRAs (CEDR, 2013)

19. A. Flammery, J. Manna, M. Venner, Life - Cycle Cost Analysis for Management of Highway Asset, in: NCHRP Synth. 494, p. 2016 (Washington DC, USA, 2016)

20. G.L. Williams, Whole Life Cost-Benefit Analysis for Median Safety Barriers (Transport Research Laboratory, 2007)

21. S.A. Cooner, Y.K. Rathod, D.C. Alberson, R.P. Bligh, E.R. Stephen, D. Sun, Performance Evaluation of Cable Median Barrier Systems in Texas. Report No. FHWA/TX-09/0-5609-1 (Texas Department of Transportation, 2009) 